\title{
Factors Affecting Maternal Attitude in Receiving the Hepatitis B Vaccine for their Infants or Children
}

\author{
Sunil Kumar ${ }^{1 *}$ and Vandana Bhagat ${ }^{2}$ \\ ${ }^{1}$ Master's in International Public Health, Australian College of Applied Psychology, Australia \\ ${ }^{2}$ BDS (India), MadvHSM, Centre for Rural Health, University of Tasmania, Australia
}

\begin{abstract}
Background and Objective: Hepatitis B is a viral infection that can cause severe complications, including damage to liver, cirrhosis, liver cancer and even death. According to the World Health Organization (WHO) (2016), globally, 240 million people are chronically infected with hepatitis B virus (HBV). Hepatitis B can be prevented with a safe and effective hepatitis B vaccination, but the maternal attitude towards the safety of vaccination can affect their choice to get their infants vaccinated or not. Therefore, this literature review used a systematic approach to understand the factors affecting the maternal attitude towards getting hepatitis $\mathrm{B}$ vaccine for their infants or children.
\end{abstract}

Methods: This study searched scientific and biomedical databases, including PubMed, Google Scholar, Cochrane Library, CINAHL, ProQuest and Web Science from 1990 to 2020 to identify relevant peer-reviewed articles. Grey literature on Hepatitis B was identified through accessing websites such as the World Health Organization, Centers for Disease Control and Prevention (CDC) and the Department of Health, Australia.

Results: From a pool of 343 articles, 12 met the eligibility criteria. Evidence suggested that parents with higher knowledge of hepatitis B vaccine and high education level were more likely to receive the hepatitis B vaccine to their children. Parents with high education level showed higher access to immunization information than parents with lower education. Parents who seek the information on vaccination from the physician were in more favour of vaccinating their infants than the parent who searched the internet for hepatitis B vaccination information.

Conclusion: This study identified that a trustworthy source of information and vaccination safety awareness among parents is associated with increased hepatitis B vaccine uptake among infants. Health education during pregnancy and visit to physicians and proper communication between the health provider and parents can be useful to improve the immunization status among infants.

KEYWORDS: Hepatitis B vaccine; Maternal attitude; Parental attitude; Factor, Barrier

\section{INTRODUCTION}

Hepatitis B is an acute and chronic viral infection of the liver that can cause severe complications, including cirrhosis or liver cancer. According to the World Health Organization (WHO) (2016), globally, 240 million people are chronically infected with the hepatitis B virus (HBV). Approximately 4.5 million people get infected with HBV infection every year and a quarter of cases with chronic HBV will progress to long term complications like cirrhosis and chronic active hepatitis [1]. HBV causes 6,86000 deaths annually. The distribution of HBV varies globally with a chronic HBV prevalence of more than $10 \%$ in parts of Southeast Asia and sub-Saharan Africa, between 2 to $8 \%$ in the Middle East and some eastern European countries and $1 \%$ in Australia, the USA and Northern Europe [2]. In Australia, the prevalence of hepatitis B is higher among Aboriginal and Torres Strait Islander, migrants from Asia and the Pacific

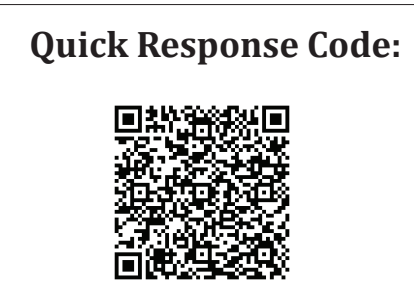

Address for correspondence: Sunil Kumar, Master's in International Public Health, Australian College of Applied Psychology, Australia

Received: July 24, $2020 \quad$ Published: August 05, 2020

How to cite this article: Sunil K, Vandana B. Factors Affecting Maternal Attitude in Receiving the Hepatitis B Vaccine for their Infants or Children. 2020 - 2(4) OAJBS.ID.000202. DOI: $10.38125 / \mathrm{OAJBS} .000202$ 
Islands, North Africa and Middle Eastern countries than the nonindigenous population [3]. In 2011, 10\% of chronic HBV cases were identified among indigenous Australians, where most infections were acquired during birth or early life. Newly acquired hepatitis B infection in 2012 was three times higher in indigenous Australian than non-indigenous Australians, with most cases among females [4]. Health literacy, access to hepatitis B screening and treatment, stigma and discrimination were common factors associated with negative health outcomes among indigenous people [5]. Sexual contact, drug use and skin penetration are the leading cause of newly acquired cases of Hepatitis B in the country [6].

Hepatitis B can also spread through a percutaneous route. Inoculation of hepatitis B virus can occur through broken skin, contact with a body fluid such as vaginal secretion or semen from an infected person, men to men sex and use of needles, syringes or razors with infected blood [7].

Perinatal transmission is a common route of transmission in developing countries [8]. In developed countries like Australia, perinatal transmission less common due to maternal HBV screening during pregnancy, low prevalence of chronic HBV and effective prophylaxis at birth [9]. Many studies reported that perinatal transmission of hepatitis B virus also depends on the maternal viral load, and infants with mothers with high viral load are at significant risk of acquiring the infection [10]. New-borns are at high risk of hepatitis infection due to vertical transmission from an infectious mother, as well as horizontal transmission from household contacts with acute or chronic HBV infection. The $80-90 \%$ of infants and 30 $50 \%$ of children who were infected during the first year of life and between 1 and 4 years of age are more likely to develop chronic HBV infection [8]. 25\% of adults who are chronically infected during childhood die from HBV related disease [8].

Hepatitis B can be prevented with hepatitis B vaccination. The first dose of hepatitis $B$ vaccine is given at the birth time. After receiving three doses, the hepatitis $B$ vaccine produces protection in more than 95\% recipients [11]. The World Health Organization (2016) recommends hepatitis B vaccine for all new-borns within 24 hours of birth followed by 2 or 3 doses of vaccine to complete the primary vaccination series. Hepatitis B vaccine is available since 1982. Australia implemented universal vaccination for all infants in 2000, and different vaccination schedules for hepatitis B were recommended for different age groups at different times [12]. According to the Australian Immunization Handbook, a dose of monovalent hepatitis B vaccine is recommended at birth or as soon as a baby is medically stable up to 7 days following birth that is followed by three doses of hepatitis B containing vaccine at 2,4 and 6 months of age for infants. Preterm infants born at $<32$ weeks gestation and low birth weight infants $<2000 \mathrm{~g}$ will also receive hepatitis B vaccine at birth, 2, 4, and 6 months of age followed by a booster dose of hepatitis $B$ containing vaccine at 12 months [13]. Hepatitis B vaccine is free under the National Immunization Program Schedule in Australia for all children aged less than ten years, as well as specific groups such as a household and sexual contacts of people with infectious HBV. In 2015, hepatitis B vaccination coverage in 12 to 15 months old was $93.6 \%$ and $85 \%$ in non-indigenous and Aboriginal and Torres Strait infants, respectively [13]. Hepatitis B screening, prophylaxis at birth and vaccination coverage has a significant contribution towards the lower prevalence of hepatitis B in the country. But a high prevalence among indigenous people and migrants, and factors that influence vaccination uptake among children creates a public health concern. Parents' positive attitude, a good understanding of vaccine-preventable disease and vaccination schedule improve vaccination rate among children [14]. Parents' belief of vaccination safety and the importance of vaccination for their child's health decides vaccination of their children [14]. This study will examine the factors influencing maternal or parental attitude towards hepatitis B vaccination to their new-borns or infants.

\section{METHODS}

We searched scientific and biomedical databases including PubMed, Google Scholar, Cochrane Library, CINAHL, ProQuest and Web Science from 1990 to 2020 using the search terms "hepatitis B vaccine* OR vaccination", "maternal attitude", "parental attitude", "factor OR factors" and "barrier OR barriers" to identifying relevant peer-reviewed articles.

Grey literature on hepatitis B was searched through a relevant organization such as the World Health Organization, Centres for Disease Control and Prevention (CDC) and the Department of Health, Australia. Retrieved peer-reviewed articles were then screened by the title and abstract and selected for further consideration based on eligibility criteria. The selected articles were then thoroughly read and were included in the review if they met the inclusion criteria. Articles were included if they reported primary data on maternal understanding and Hepatitis B vaccination, factors affecting maternal and parental attitude, vaccination uptake among pregnant women and new-born. Peer-reviewed articles were considered if they were published between 1990 and 2020 in the English language and if the full text was available. The Snowballing technique was also used to identify potentially relevant studies through references in the identified articles. The search results were reviewed by the author by title and abstract of the identified articles.

\section{RESULTS}

The initial search identified 343 articles that were then screened by title and abstracts. Fourteen duplicate articles were identified and removed. 235 articles were excluded after screening their titles and abstracts. The 94 articles were assessed by the full text that resulted in thirteen articles. The PRISMA flow chart was used to document the literature search and selection process of this study (Figure 1). All the included studies focus on the knowledge and attitude of the mother or both parents in receiving the hepatitis $B$ vaccine to their infants or new-borns (Table 1).

\section{Knowledge/ Health Literacy and Education Level}

Knowledge of hepatitis B immunization among parents is an important factor in higher uptake of this vaccine that is directly associated with education level and age of the mother or both parents $[15,16]$. Hepatitis B knowledge was higher among parents with post-secondary education than among those with a lower level of education $[17,18]$. Study in Sweden showed that willingness to accept hepatitis B vaccine was higher among mothers with postschool education. Parents wanted to gain more knowledge on immunization schedule and its benefits for making the right decision to vaccinate their children. The study conducted in Italy stated that $87 \%$ of participants ( $n=841$ ) with knowledge of hepatitis B vaccine thought to receive the vaccination for their new-born [19]. Mothers with higher knowledge of immunizations had greater coverage of full immunization for their children. The education level of parents is also related to access to immunization information. Parents with post-secondary education accessed sufficient immunization information for their children while parents with a low education level were less likely to have sufficient information on vaccination schedule (OR= 4.1, 95\% CI= 1.2-14.4) (19). 


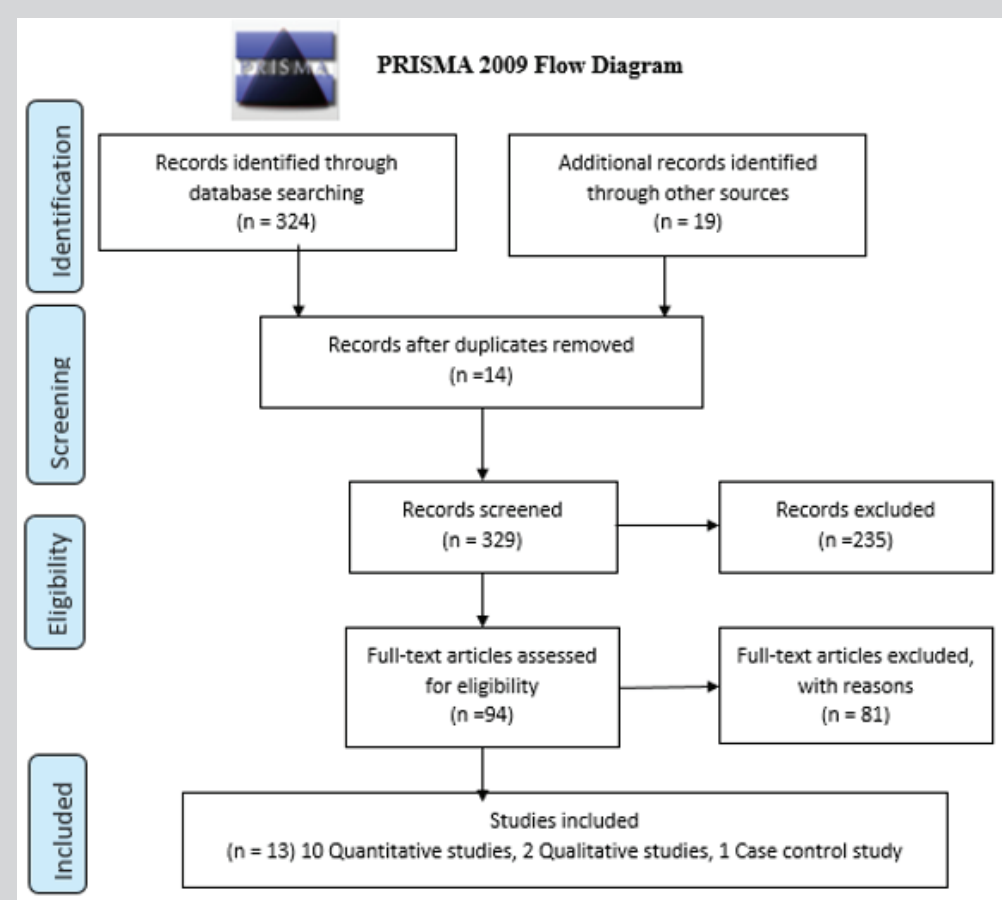

Figure 1: PRISMA flow chart of literature and reviews process [15].

Table 1:

\begin{tabular}{|c|c|c|c|c|c|c|}
\hline Reference & Year & Methods & Population & Location & Study Focus & Key Findings \\
\hline $\begin{array}{c}\text { Angelillo } \\
\text { IF, Ricciardi } \\
\text { G, Rossi P, } \\
\text { Pantisano P, } \\
\text { Langiano E, } \\
\text { Pavia M }\end{array}$ & 1990 & $\begin{array}{l}\text { Quantitative: } \\
\text { self- } \\
\text { administrated } \\
\text { survey }\end{array}$ & Mothers & Italy & $\begin{array}{l}\text { Knowledge and } \\
\text { attitude towards } \\
\text { Hepatitis B } \\
\text { vaccination }\end{array}$ & $\begin{array}{l}53 \% \text { of mothers knew about all the four vaccines. } \\
87 \% \text { agreed to receive the hepatitis B vaccine to } \\
\text { their infants, but 3rd dose uptake was only } 56 \% .45 \\
\% \text { of mothers accept that side effects of vaccination } \\
\text { are the most important determinants of their values. } \\
\text { Main reasons for not accepting the vaccine to their } \\
\text { children were no advice from a physician, safety } \\
\text { concern and no need for the vaccine. Physicians } \\
\text { were the main source of information (70\%). }\end{array}$ \\
\hline $\begin{array}{c}\text { Bardenheier, } \\
\text { BH, Yusuf HR, } \\
\text { Rosenthal J, } \\
\text { Santoli JM, } \\
\text { Shefer AM, } \\
\text { Rickert DL, } \\
\text { Chu SY }\end{array}$ & 2004 & $\begin{array}{l}\text { Qualitative: } \\
\text { face to face } \\
\text { interview } \\
\text { Quantitative: } \\
\text { questionnaire }\end{array}$ & $\begin{array}{c}\text { Parents and } \\
\text { caregivers }\end{array}$ & USA & $\begin{array}{l}\text { Factors associated } \\
\text { with under } \\
\text { immunization }\end{array}$ & $\begin{array}{l}\text { Education, firstborn status and income was a } \\
\text { significant factor related to under immunization. }\end{array}$ \\
\hline $\begin{array}{l}\text { Benin AL, } \\
\text { Wisler-Scher } \\
\text { DJ, Colson E, } \\
\text { Shapiro ED, } \\
\text { Holmboe ES }\end{array}$ & 2006 & $\begin{array}{l}\text { Qualitative: } \\
\text { Telephone } \\
\text { interviews }\end{array}$ & Mothers & USA & $\begin{array}{l}\text { Attitude toward } \\
\text { the vaccination }\end{array}$ & $\begin{array}{l}\text { Trust on a physician, a reliable source of information } \\
\text { was the promoter of vaccination. In contrast, distrust } \\
\text { on a physician, fear of side effects and perception } \\
\text { that vaccine is not necessary acted like inhibitor. }\end{array}$ \\
\hline $\begin{array}{c}\text { Bigham M, } \\
\text { Remple VP, } \\
\text { Pielak K, } \\
\text { McIntyre C, } \\
\text { White R, Wu } \\
\text { W }\end{array}$ & 2006 & $\begin{array}{l}\text { Quantitative: } \\
\text { Telephonic } \\
\text { interviews }\end{array}$ & Parents & $\begin{array}{l}\text { British } \\
\text { Columbia }\end{array}$ & $\begin{array}{l}\text { Attitudinal and } \\
\text { behavioural } \\
\text { determinants } \\
\text { of vaccination } \\
\text { uptake }\end{array}$ & $\begin{array}{l}\text { 87\% of infants received at least one dose of hepatitis } \\
\text { B vaccine, and } 78 \% \text { took three doses. A reliable } \\
\text { source of information, physician influence, trust, } \\
\text { attention to parents' safety concern issues were the } \\
\text { main factors toward uptake. }\end{array}$ \\
\hline
\end{tabular}




\begin{tabular}{|c|c|c|c|c|c|c|}
\hline $\begin{array}{l}\text { Celikel A, } \\
\text { Ustunsoz A, } \\
\text { Guvenc G }\end{array}$ & 2014 & $\begin{array}{l}\text { Quantitative: } \\
\text { questionnaire }\end{array}$ & $\begin{array}{l}\text { Pregnant } \\
\text { women }\end{array}$ & Turkey & $\begin{array}{l}\text { Factor affecting } \\
\text { vaccination } \\
\text { among pregnant } \\
\text { women }\end{array}$ & $\begin{array}{l}\text { The vaccination rate was higher among younger } \\
\text { women than older. Doctor recommendation and } \\
\text { information about vaccination were the most } \\
\text { effective reason for getting a vaccine. Safety concern, } \\
\text { prior vaccination and not advised by the doctor } \\
\text { contributed toward non-vaccination status. }\end{array}$ \\
\hline $\begin{array}{l}\text { Dannetun } \\
\text { E, Tegnell A, } \\
\text { Giesecke J }\end{array}$ & 2007 & $\begin{array}{l}\text { Quantitative: } \\
\text { Questionnaire }\end{array}$ & Parents & Sweden & $\begin{array}{l}\text { Parent's } \\
\text { knowledge and } \\
\text { attitude toward } \\
\text { hepatitis B } \\
\text { vaccination }\end{array}$ & $\begin{array}{l}\text { The majority of parents with high education thought } \\
\text { to receive the hepatitis B vaccine to their children }\end{array}$ \\
\hline $\begin{array}{l}\text { Eyeson-Annan } \\
\text { M, Correll PK, } \\
\text { Hayen A }\end{array}$ & 2003 & $\begin{array}{l}\text { Quantitative: } \\
\text { Telephone } \\
\text { interviews }\end{array}$ & Parents & $\begin{array}{l}\text { New South } \\
\text { Wales, } \\
\text { Australia }\end{array}$ & $\begin{array}{l}\text { Knowledge and } \\
\text { attitude towards } \\
\text { hepatitis B } \\
\text { vaccine }\end{array}$ & $\begin{array}{c}80 \% \text { of parents were not aware of free vaccine. Only } \\
32 \% \text { of parents advised getting a vaccine. Source } \\
\text { of information: } 50 \% \text { Health professionals and } 36 \% \\
\text { media. }\end{array}$ \\
\hline $\begin{array}{c}\text { Giao H, Quang } \\
\text { Vinh B, Huynh } \\
\text { Tam Lang N, } \\
\text { Le An P }\end{array}$ & 2019 & Quantitative & $\begin{array}{l}\text { Parents and } \\
\text { caregivers }\end{array}$ & Vietnam & $\begin{array}{l}\text { Factors affecting } \\
\text { timely and full } \\
\text { Hepatitis B } \\
\text { vaccination }\end{array}$ & $\begin{array}{l}\text { Demographic location, health worker advice and } \\
\text { information on vaccination is associated with timely } \\
\text { and full Hepatitis B vaccination. }\end{array}$ \\
\hline $\begin{array}{l}\text { Gust D, } \\
\text { Kennedy A, } \\
\text { Shui I, Smith } \\
\text { PJ, Nowak G, } \\
\text { Pickering LK }\end{array}$ & 2005 & $\begin{array}{l}\text { Quantitative: } \\
\text { Self-reported } \\
\text { survey }\end{array}$ & Parents & USA & $\begin{array}{l}\text { Attitude towards } \\
\text { immunization } \\
\text { and healthcare } \\
\text { providers }\end{array}$ & $\begin{array}{c}67 \% \text { had access to vaccination information. } 33 \\
\% \text { were without vaccine information, had safety } \\
\text { concern and distrust to a doctor that was related to } \\
\text { lower education. }\end{array}$ \\
\hline $\begin{array}{l}\text { Maayan- } \\
\text { Metzger } \\
\text { A, Kedem- } \\
\text { Friedrich P, } \\
\text { Kuint J }\end{array}$ & 2005 & $\begin{array}{l}\text { Case-control } \\
\text { study }\end{array}$ & Mothers & Israel & $\begin{array}{l}\text { Mothers' attitude } \\
\text { toward hepatitis B } \\
\text { immunization }\end{array}$ & $\begin{array}{l}16 \% \text { of the study group supported full immunization } \\
\text { to their children. Main reasons for not supporting } \\
\text { the vaccination of their children were safety } \\
\text { concerns ( } 30 \%) \text {, misconception such as vaccine } \\
\text { being not suitable for infants ( } 54 \%)\end{array}$ \\
\hline $\begin{array}{c}\text { Mergler MJ, } \\
\text { Omer SB, Pan } \\
\text { WK, Navar- } \\
\text { Boggan AM, } \\
\text { Orenstein W, } \\
\text { Marcuse EK, } \\
\text { Damico A }\end{array}$ & 2013 & $\begin{array}{l}\text { Quantitative: } \\
\text { questionnaire }\end{array}$ & $\begin{array}{l}\text { Parents and } \\
\text { health care } \\
\text { providers }\end{array}$ & USA & $\begin{array}{l}\text { Attitude and } \\
\text { beliefs of health } \\
\text { care providers } \\
\text { and parents } \\
\text { toward children } \\
\text { vaccination }\end{array}$ & $\begin{array}{l}\text { Parents had greater believe in vaccination safety } \\
\text { if their healthcare providers recommended the } \\
\text { vaccine. Healthcare providers as a source of } \\
\text { information and their credibility encouraged parents } \\
\text { to receive a vaccine to their children. Majority of } \\
\text { healthcare providers believed that vaccination is } \\
\text { beneficial to children and the community ( } 90 \%) \text {. }\end{array}$ \\
\hline $\begin{array}{l}\text { Prosser N, } \\
\text { Petersen R, } \\
\text { Quinlivan J }\end{array}$ & 2016 & $\begin{array}{l}\text { Quantitative: } \\
\text { Self-reported } \\
\text { survey }\end{array}$ & Parents & Australia & $\begin{array}{l}\text { Attitude } \\
\text { toward infant } \\
\text { immunization }\end{array}$ & $\begin{array}{l}\text { Positive attitude towards immunization were } \\
\text { associated with reliable sources of information } \\
\text { and discussing the issue with doctors. Majority of } \\
\text { parents supported infant immunization. Only } 2 \% \text { of } \\
\text { participants had a negative attitude toward infant } \\
\text { vaccination. Main reasons for negative attitude } \\
\text { were self-reporting a higher level of knowledge and } \\
\text { seeking information on the internet than health } \\
\text { professionals. Health care professionals were the } \\
\text { main source of information (71\%), followed by } \\
\text { friends and family members (18\%). }\end{array}$ \\
\hline $\begin{array}{l}\text { Thompson } \\
\text { MJ, Taylor } \\
\text { VM, Jackson } \\
\text { JC, Yasui Y, } \\
\text { Kuniyuki A, } \\
\text { Tu S, Hislop } \\
\text { TG }\end{array}$ & 2002 & $\begin{array}{l}\text { Quantitative: } \\
\text { questionnaire }\end{array}$ & Women & $\begin{array}{l}\text { Washington, } \\
\text { USA }\end{array}$ & $\begin{array}{l}\text { Hepatitis B } \\
\text { knowledge }\end{array}$ & $\begin{array}{l}\text { Lack of knowledge. } 56 \% \text { of participants knew about } \\
\text { hepatitis B, } 23 \% \text { knew it could be transmitted from } \\
\text { person to person }\end{array}$ \\
\hline
\end{tabular}




\section{Source of Information and Immunization Recommendation}

A reliable source of information and its credibility influences the attitude of parents towards vaccination [20]. Family physicians or healthcare providers are the main sources of information, and more than half of the participants seek immunization information from healthcare professionals [16,20-25]. Doctors recommendation and advice was the most effective reason for receiving the hepatitis B vaccine among pregnant women [23]. Parents who gained vaccination information from health workers and followed the advice on vaccination received timely and full Hepatitis B vaccination for their children [26]. The attitude of healthcare professionals also determines the distribution of vaccination information among mothers or parents of the newborn. Physicians who favoured the importance of vaccination strongly supported hepatitis B vaccination to new-borns and immunization information to pregnant women and parents [27] This study found that $80 \%$ of physicians $(n=76)$ thought it was important to give the first dose of hepatitis B vaccine at birth. Half of the physicians provided hepatitis B immunization information to all the pregnant women and parents. A study by Mergler et al. [19] found that most health providers ( $97 \%, n=551)$ believed there were benefits of vaccination to children and recommended the three-dose of hepatitis B vaccination for children.

\section{Safety Concerns and Perceptions Towards Immunization}

Safety concerns such as possible side effects of the vaccine and the vaccine being painful for infants is a major barrier in hepatitis $B$ vaccine uptake. Various studies identified that safety concern is associated with a lower education level of parents, less access to immunization information, not enough communication with health providers and perception toward vaccination [19,23]. A study conducted in the USA revealed that 33\% of participants ( $n=642$ ) who had safety concerns with receiving the vaccine to their children accepted that they had not enough access to the vaccine information [19]. Discussion with health care professionals or physician helped in building trust towards immunization and increased vaccination uptake among children. Majority of parents agreed to vaccinate their children if their healthcare providers recommended vaccination and if they believed in vaccination safety [20]. The study by Maayan-Metzger, Kedem-Friedrich, Kuint 2005 found that $30 \%$ of mothers refused hepatitis B vaccination to their children because of the safety concern while $54 \%$ of participants believed that vaccines were not suitable for newborn or infants $(n=153)$. Parents' perceptions of vaccination risks or perceived benefits also determine their attitude to vaccinate their children or not. Parents who had positive attitudes and were encouraged by friends or family members or surroundings to vaccinate their children were in favour of immunization and had low susceptibility attitude toward vaccination safety concern [28]. Parents who accessed the internet for hepatitis B information showed negative attitudes towards vaccination, the high tendency of self-reporting higher knowledge of hepatitis B and misconception, such as no need of vaccination to healthy children.

\section{Trust in Healthcare Professionals}

Trust in healthcare providers and the credibility of the information provided by them helped to build positive attitudes of parents towards infant immunization. Mother or both parents' satisfaction toward vaccination discussion with the physician and their opinion that their physician was knowledgeable and had all the relevant information was important to make a trustworthy relationship with healthcare providers [21]. Most of the studies showed that parents preferred their family physicians for vaccine information because of their trust in them. Such attitudes of parents were associated with spending more time with a physician, discussing vaccine-related question for a sufficient length of time, and feeling comfortable to discuss any safety issue. Parents showed high confidence toward vaccination safety and agreed to receive a vaccine if their health care providers had positive beliefs regarding vaccine safety and vaccine benefits to children [20]. Distrust in healthcare professionals and negative experiences with health providers or medical staff was also related to refusal to the vaccine or not completing immunization schedule [29]. 31\% of parents $(n=392)$ reported that negative experience with medical staff during their immunization visit influenced their children's immunization status [29]. Another study conducted in South Western Sydney also reported that attitudes of healthcare practitioners were related to vaccination status of children [30]. $41 \%$ of families $(n=149)$ answered that they forgot to complete immunization schedule because they did not receive any notification from their healthcare provider to continue immunization schedule [30].

\section{DISCUSSION}

This narrative literature review used a systematic approach to identify the factors influencing maternal attitude in receiving the hepatitis B vaccine to their new-born. This study shows that knowledge on hepatitis B vaccine, maternal education level, reliable source of information and trust on the physician is the significant promoter of neonatal hepatitis B vaccination while vaccination safety concern is identified as the main barrier in vaccine uptake.

Knowledge of hepatitis B disease and vaccine among mother or both parents are significantly associated with the immunization status of the new-born. Parents with greater knowledge of hepatitis B were more likely to vaccinate their children. Knowledge of vaccination schedule or due vaccination and knowledge of vaccination benefits among parents is associated with a high immunization rate. Knowledge regarding vaccination depends on the source of information and communication between parents and information providers. Lack of communication with healthcare providers and inadequate information on the vaccination status of children can lead to missed immunization opportunities or delay vaccination. Many studies identified the association between knowledge and source of information. For example, a study conducted in the USA revealed that children of parents with adequate knowledge on a vaccination schedule and sufficient communication with a physician for vaccination information had significantly higher immunization coverage [31]. Mother understanding on correct age of a child to begin immunization and total dose of vaccination uptake can play an important role in receiving timely vaccination. Frequency of mother' visits to antenatal care (ANCs) and parental care during pregnancy also affect the immunization status among children. Health education, regular check-ups, suggestion on vaccine-preventable diseases (VPDs) on visits to ANCs and regular notification on vaccination can build a positive attitude among pregnant women regarding vaccine need to their new-borns. Discussion with a healthcare professional regarding health risk during pregnancy and after pregnancy, mandatory vaccination and other important vaccines for mothers and new-born may not only increase mother or parents' knowledge and awareness, but it can also build their confidence on vaccination safety. 
Understanding among parents or mother on the purpose of vaccine given to new-born or children can help to improve immunization status of infants, and it is seen that knowledge and awareness about vaccination are higher among the parent or mothers with higher education level. For example, a study in Netherland showed that hepatitis B knowledge was higher among the parents with vocational education and post-secondary education as compared to parents with below post-secondary education [32]. Parents with lower education level shows high concern regarding vaccination safety that can be due to lack of proper communication with healthcare professionals, lack of information, misconceptions such as no need of vaccine to their children and inherited immunity. Hepatitis B education during pregnancy makes mothers and parents aware and increases their understanding of vaccination. They support immunization positively for their children.

Source of information and access to information is another factor affecting mothers' attitude toward new-born vaccination. Physicians and nurses are the first point of information for pregnant women relating to immunization. But it is identified that mothers or parents who did not discuss immunization issues with physician showed lower access to vaccination information. Literacy level and vaccination hesitancy could be a supportive factor behind communication gap between physician and parents. Sometimes, parents may not have an idea of what they should have to discuss with physicians about vaccination. Parents search for other information sources such as the internet also. Use of the internet has significantly increased in recent years and has been serving as a wide source of information, including health and vaccination [33]. Rapid and wide access to the internet made it impossible to regulate health-related information. But a large proportion of online information regarding immunization reached to parents has anti-vaccination content, incomplete and published in a misleading fashion that affects parents' attitude toward vaccination need and safety [33]. A study in the USA showed that internet users (parents who used internet for vaccination information) were more likely to refuse new-born or children immunization than non-internet users (parents who preferred physicians for vaccination information) [33]. Internet users were less likely to believe in vaccination safety and had a lower perception of disease susceptibility and vaccine benefits. Parents accessing the information on the web were more likely to believe that healthy children do not need any vaccination. Another survey conducted in Australia also revealed that the majority of parents who opposed vaccination access internet for immunization information. Excessive use of the internet for information over physician appointments, variety of immunization information and reliability of this information might shape their intention to vaccination with high self-reporting of knowledge that can lead to vaccination refusal or incomplete vaccination. So, it becomes important to access a reliable source of information such as government websites and medical research institute's sources for immunization information.

Vaccination safety is also a significant issue to affect immunization uptake among children. Physician recommendation to children vaccination, providing information and discussing vaccination need with mothers or both parents can build trust and confidence among parents regarding vaccination safety. Parents expressed their concern to many vaccines at a younger age that can be painful and cause adverse effects to children. Regular discussion with healthcare providers and immunization education to parents or pregnant women can help to raise the trust in vaccination safety.
Parents' attitude toward immunization and trust in health care workers are directly interlinked to each other. The reputation of a physician, credibility of information provided by physician, friends and neighbours views to healthcare provider make people comfortable and build trust in the health practitioner. Parents like to discuss vaccination benefits and support the immunization if their physician shows interest in their concern regarding vaccination, and this can be an opportunity to build parents trust on vaccination safety. Healthcare providers' discussion on the management of vaccination side effects, quantification of the risk of vaccination and non-vaccination and responding to specific concern in a positive way can encourage parents to vaccinate their children.

\section{LIMITATIONS}

We found only a limited number of studies on hepatitis B vaccine and parental attitude in developed countries. Majority of studies used self- reported questionnaires that could resulted in biased responses.

\section{CONCLUSION}

This study increases our understanding of the factors that affect maternal or parental attitude in receiving hepatitis B to their new-borns. Our study identified that knowledge on hepatitis B vaccine, source of information and vaccination safety awareness is associated with hepatitis B vaccine uptake among new-borns. Further research is needed to understand the effect of other factors such as income, work occupation and influence of physician on parents' attitude. Health education during pregnancy and visit to physicians and proper communication between the health provider and parents can be useful to improve the immunization status among children.

\section{REFERENCES}

1. Franco E, Bagnato B, Marino MG, Meleleo C, Serino L, et al. (2012) Hepatitis B: Epidemiology and prevention in developing countries. World journal of hepatology 4(3): 74-80.

2. (2019) Hepatitis B. World Health Organisation.

3. (2016) The Australian immunisation handbook: Hepatitis B. Australian government.

4. Australia H (2014) Hepatitis B testing and treatment in Australia's indigenous communities: Hepatitis Australia national advocacy priority.

5. (2014-2017) The department of health. Second national hepatitis B strategy. Australian government.

6. (2018) Hepatitis B: Australian government.

7. (2016) World Health Organization. Hepatitis B

8. Levy MT, Wiseman E (2009) Perinatal transmission of hepatitis B virus: An Australian experience. Medical Journal of Australia 191(6): 357.

9. Wiseman E, Fraser MA, Holden S, Glass A, Kidson BL, et al. (2009) Perinatal transmission of hepatitis B virus: an Australian experience. The Medical Journal of Australia 190(9): 489.

10. (2015) Hepatitis B vaccines for Australians: Information for immunisation providers.

11. (2016) Department of Health. Hepatitis B.

12. (2016) The Australian immunisation handbook: Hepatitis B. Department of Health.

13. Favin M, Steinglass R, Fields R, Banerjee K, Sawhney M (2012) Why children are not vaccinated: a review of the grey literature. International health 4(4): 229-238. 
14. Liberati A, Altman DG, Tetzlaff J, Mulrow C, Gøtzsche PC, et al. (2009) The PRISMA statement for reporting systematic reviews and meta-analyses of studies that evaluate health care interventions: explanation and elaboration. Journal of Clinical Epidemiology 62(10): e1-e34.

15. Angelillo IF, Ricciardi G, Rossi P, Pantisano P, Langiano E, et al. (1999) Mothers and vaccination: knowledge, attitudes and behaviour in Italy. Bulletin of the World Health Organization 77(3): 224-229.

16. Dannetun E, Tegnell A, Giesecke J (2007) Parents' attitudes towards hepatitis B vaccination for their children. A survey comparing paper and web questionnaires, Sweden 2005. BMC public health 7(1): 86.

17. Bardenheier BH, Yusuf HR, Rosenthal J, Santoli JM, Shefer AM, et al. (2004) Factors associated with underimmunization at 3 months of age in four medically underserved areas. Public Health Reports 119(5): 479485.

18. Gust DA, Kennedy A, Shui I, Smith PJ, Nowak G, et al. (2005) Parent attitudes toward immunizations and healthcare providers: the role of information. American Journal of Preventive Medicine 29(2):105-112.

19. Mergler MJ, Omer SB, Pan WK, Navar-Boggan AM, Orenstein W, et al. (2013) Association of vaccine-related attitudes and beliefs between parents and health care providers. Vaccine 31(41): 4591-4595.

20. Benin AL, Wisler-Scher DJ, Colson E, Shapiro ED, Holmboe ES (2006) Qualitative analysis of mothers' decision-making about vaccines for infants: The importance of trust. Pediatrics 117(5): 1532-1541.

21. Bigham M, Remple VP, Pielak K, McIntyre C, White R, et al. (2006) Uptake and behavioural and attitudinal determinants of immunization in an expanded routine infant hepatitis B vaccination program in British Columbia. Canadian Journal of Public Health 97(2): 90-95.

22. Celikel A, Ustunsoz A, Guvenc G (2014) Determination of vaccination status of pregnant women during pregnancy and the affecting factors. J Clin Nurs 23(15-16): 2142-2150.

23. Eyeson-Annan M, Correll PK, Hayen A (2003) Hepatitis B immunisation in children aged 10-13 years in New South Wales, 2001. New South Wales Public Health Bulletin 14(1): 17.
24. Prosser N, Petersen R, Quinlivan J (2016) Survey of Australian father's attitudes towards infant vaccination: Findings from the Australian father's study. Primary Health Care 6(228): 1000228.

25. Giao H, Quang VB, Huynh TLN, Le An P (2019) Parents' Attitude about Hepatitis B disease and practice of hepatitis B vaccination among children in Ho Chi Minh City, Vietnam. BioMed Research International.

26. Zola J, Smith N, Goldman S, Woodruff BA (1997) Attitudes and educational practices of obstetric providers regarding infant hepatitis $B$ vaccination. Obstet Gynecol 89(1): 61-64.

27. Harmsen IA, Lambooij MS, Ruiter RA, Mollema L, Veldwijk J, et al. (2012) Psychosocial determinants of parents' intention to vaccinate their newborn child against hepatitis B. Vaccine 30(32): 4771-4777.

28. Stockwell MS, Irigoyen M, Martinez RA, Findley S (2011) How parents' negative experiences at immunization visits affect child immunization status in a community in New York City. Public Health Reports 2011: 24-32.

29. Lam LP, McLaws ML (1998) Hepatitis B vaccination coverage of Vietnamese children in south-western Sydney. Australian and New Zealand Journal of Public Health 22(4): 502-504.

30. McCormick L, Bartholomew L, Lewis M, Brown M, Hanson I (1997) Parental perceptions of barriers to childhood immunization: results of focus groups conducted in an urban population. Health Education Research 12(3): 355-362.

31. Hontelez JAC, Hahné SJM, Oomen P, de Melker H (2010) Parental attitude towards childhood HBV vaccination in the Netherlands. Vaccine 28(4): 1015-1020.

32. Jones AM, Omer SB, Bednarczyk RA, Halsey NA, Moulton LH, et al. (2012) Parents' source of vaccine information and impact on vaccine attitudes, beliefs and nonmedical exemptions. Advances in preventive medicine.

33. Pemberton S (2013) 50\% of Australians who oppose vaccination get their information from the Internet. 